\title{
Tracing Footprints of a Bygone Era: Kaleshwari complex, Lavana
}

\author{
Maulik Hajarnis \& Bhagyajit Raval \\ Faculty of Architecture, Parul University, Waghodia, Vadodara, Gujarat, India. \\ EMail IDs: hajarnismaulik@gmail.com, bhagyajit.raval@gmail.com
}

\begin{abstract}
The paper begins with a background of the study wherein the heritage potentials of the Panchmahal region are discussed, wherein 'Kaleshwari' is mentioned as one of the archaeological sites in the region. The next portion of the paper unfolds the details of this State Protected group of monuments like the Architectural significance of the site, etymology, geographical location and other important details about the site like the then logic behind the selection of the site, flora and fauna, etc. Each monument out of the group of protected monuments at the site is then analysed from an architectural perspective. The paper concludes with a way forward wherein the further scope of research and restoration is written down.
\end{abstract}

Keywords: Kaleshwari, Panchmahal, Vaav, Chauri, Mandir

\section{Introduction}

Panchmahal region in Gujarat is one of the richest regions in terms of its cultural heritage, antiquities, architectural marvels, dense forests and natural ecosystems of flora and fauna. The cultural heritage of this region is backed by numerous ancient monuments in Champaner, Pavagadh, Halol, Lunawada, Santrampur, Devgadh Baria, 'Kaleshwari', etc.

At the zenith of the architectural glory is of course Champaner-Pavagadh by being a World Heritage Site. But still there are other several less known monumental sites in the region which have not yet been publicized to their fullest potential. Such sites include several monuments at varied locations in the region, some of them being the archaeological site of 'Kaleshwari', several palaces of Lunawada, Devgadh Baria, Jambughoda, Santrampur, Limbadiya and Sanjeli, etc. This paper attempts to popularize less known yet worthy to cherish monuments of the complex at 'Kaleshwari'.

\section{About 'Kaleshwari' - the site}

\section{Etymology of 'Kaleshwari'}

The word 'Kaleshwari' seems to have been derived from either 'Kalashri', or 'Kala+Ishwari' (Goddess of art) or 'Klesh+Hari' (Goddess who takes away all your disputes $\mathcal{E}$ sorrows). Out of these the third alternative seems to be more appropriate. (Gandhi, 1953)

(c) AesthetixMS 2016. This Open Access article is published under a Creative Commons Attribution Non-Commercial 4.0 International License (http://creativecommons.org/licenses/by-nc/4.o/), which permits non-commercial re-use, distribution, and reproduction in any medium, provided the original work is properly cited. For citation use the DOI. For commercial re-use, please contact editor@chitrolekha.com 

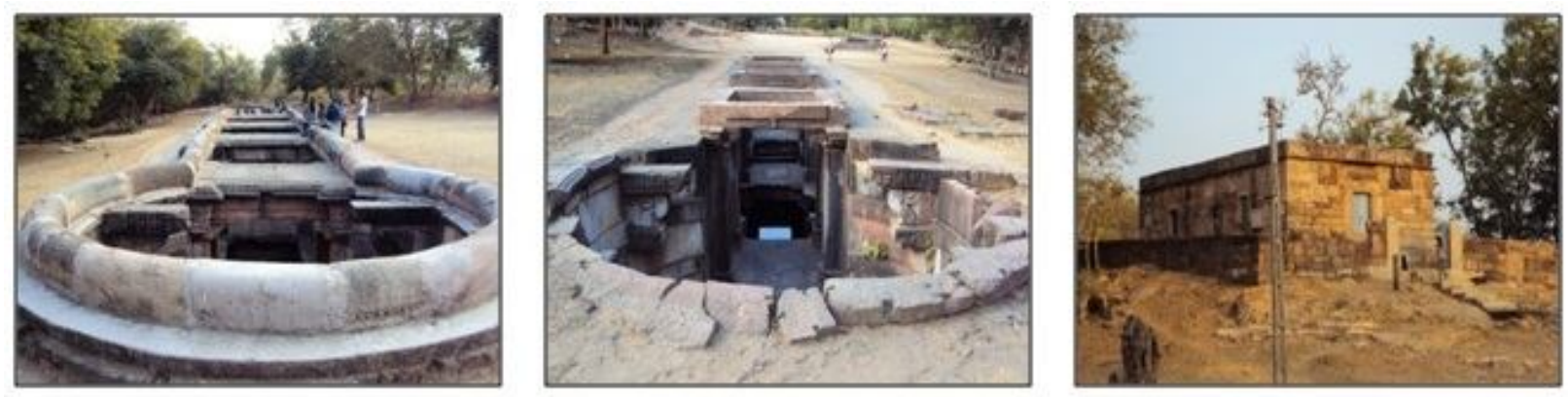

Fig. 1 Saasu ni Vaav (left), Vahu ni Vaav (centre) \& Shikaar Madhi (right)
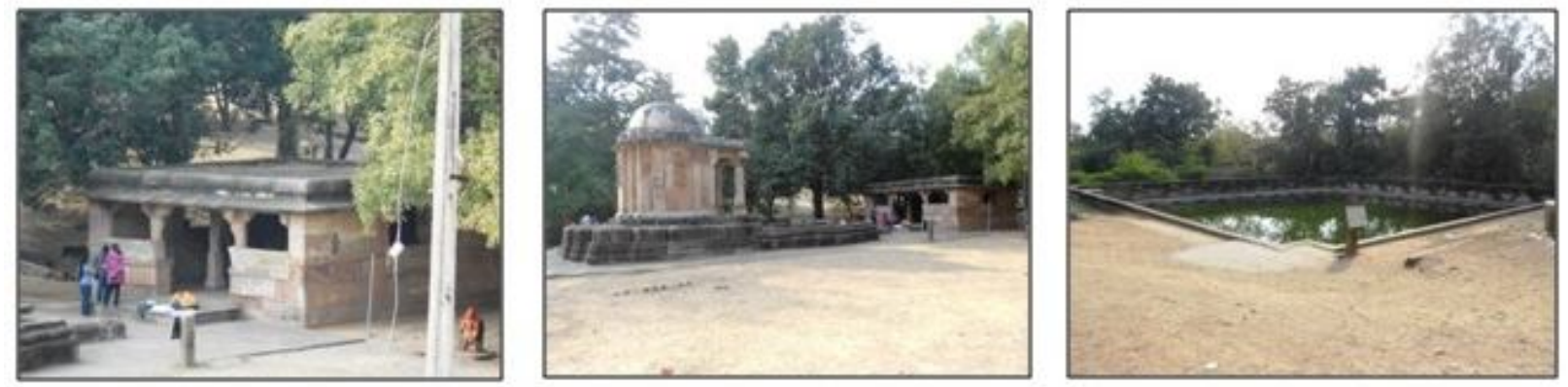

Fig. 2 Kaleshwari Mata Mandir (left), Shiv Mandir (centre) \& Kund (right)
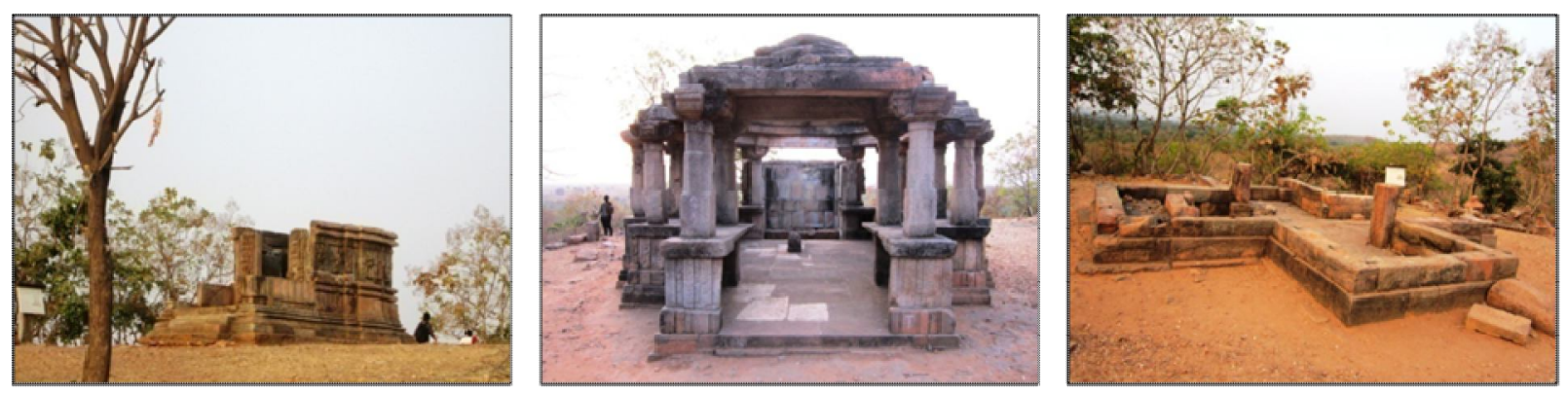

Fig. 3 Arjun ni Chauri (left), Bhim ni Chauri (centre) \& Hidamba Temple (right)

\section{Geographical location, selection of the site and other important details}

'Kaleshwari' or 'Kaleshwari ni naal' $\left(23^{\circ}-20^{\prime} \mathrm{N}, 73^{\circ}-34^{\prime} \mathrm{E}\right)$ is a significant archaeological and historical site situated about $20 \mathrm{kms}$. to the north of Lunawada on the Lunawada - Modasa road, in the Panchmahal district of Gujarat State. It is a 'naal' or 'valley' formed in the range of hills stretching from the east to the west. Locally these hills are known as 'Ghato' or 'Kasai no dungar'. It is a small picturesque valley surrounded by low hillocks of quartzite having veins of quartz. It is believed that the site was selected for constructing the complex since it was situated on the old trade route from Gujarat to Rajasthan; so, that the travellers could halt for some time, rest there and fetch water from the stepwells. Water, again is an auspicious element in our religion which is why religious structures and sculptures always go alongwith it. However, it must be noted that the two constructions listed below were later additions to the original group of monuments at the complex:

1. The Shikaar Madhi was a later addition to the complex by Vakhatsinh Baavaji (popularly known as the Bungalow) and 
2. The sculpture gallery which was an initiative of the Archaeology Department of the Gujarat State.

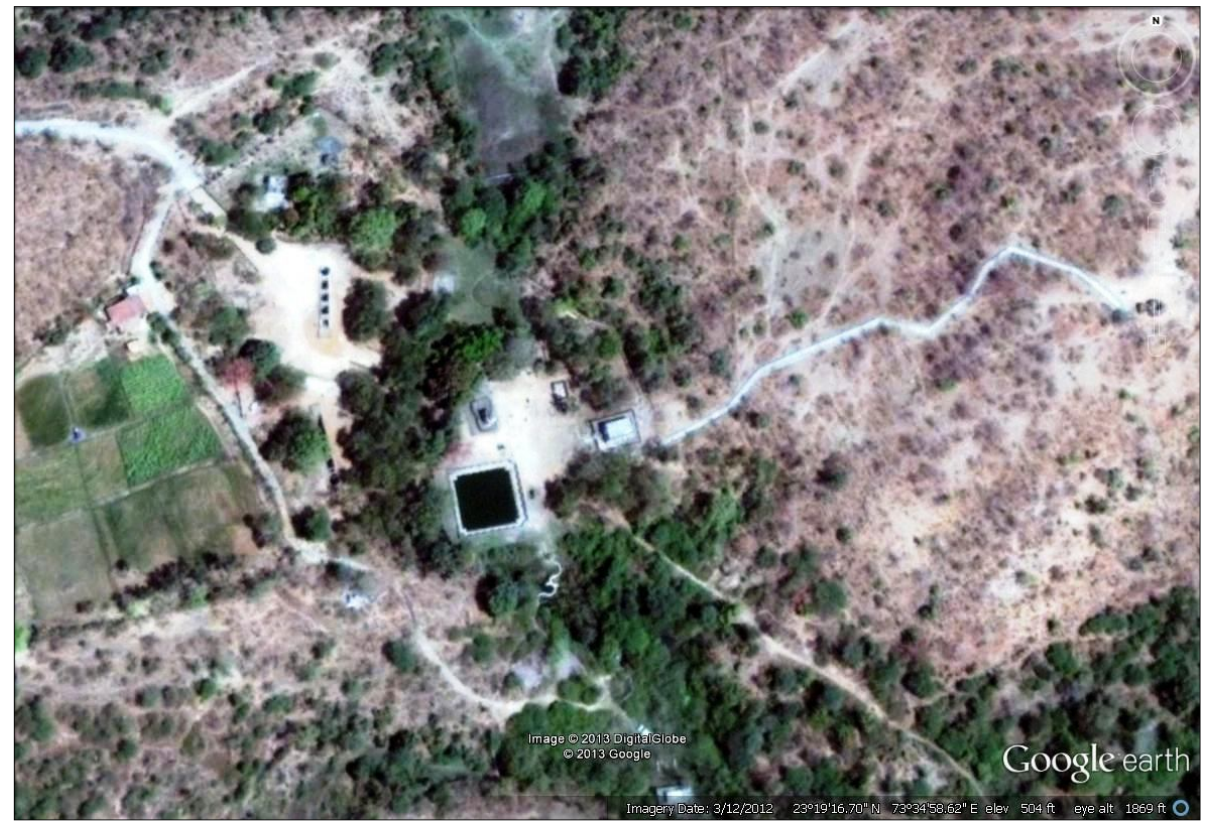

Fig. 4 Aerial view of Group of monuments at Kaleshwari, Lavana, Panchmahal, Gujarat (Source: Google earth - 2013)

As evident from the above image, the gradient natural gradient of the land slopes towards the portion of land where the Kund and the Stepwells are constructed. Therefore, the flow of water used to naturally occur in these water monuments and earlier there were streams of water oozing out from several points at site.

\section{Flora and fauna}
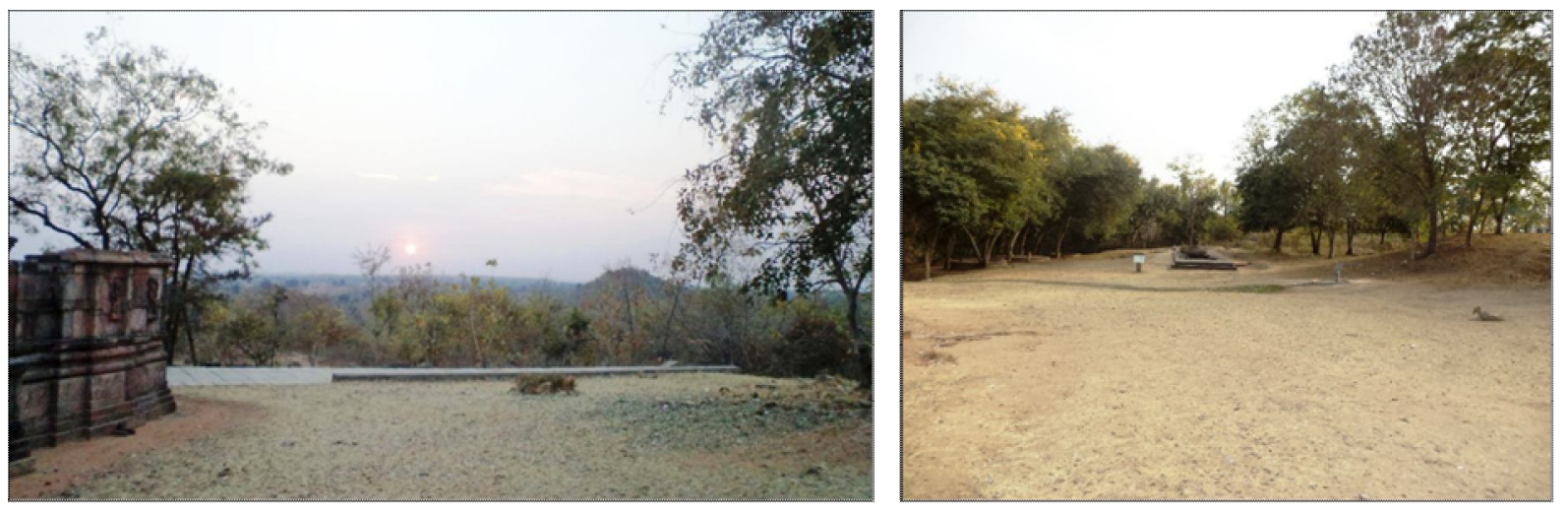

Fig. 5 Greenery and forest in and around the site - Kaleshwari

During the rainy season, the whole hillock gets illuminated with white sarina flower. Blossom and fragrance of these florescent make the atmosphere divine, healthy and beautiful. Dr. M.R Majumdar writes that Kaleshwari till yesterday was accessible as river Mahi intercepts the road leading to the solitary place through hills and thick jungle. (Majumdar, 1958) 
There is a beautiful natural fountain stream oozing from the north ground and rushing towards the south. This pure cold water fountain makes a clattering sound which adds a quiver to the serenity of the environment. Other flora at the site includes trees of date palm (Khajuri), Sadad, Sagada, Kanaj and Pipal. Greenery of grass, creepers and trees are all worthy to note. (Hajarnis, 1990)

It is a great experience to see and fill glittering light of fireflies in the gloomy dark night at Kaleshwari. Gandhi noted in 1953 rarely, tigers also appear here. This means in earlier times tigers were in a good number here at Ghato dungar. During the state time, jungles of Ghato hills were cleared or cut off. This left the site unfit for the wild animals to stay. Other reason for the extinction of the tigers in the region was the killing of tigers, which was a royal tradition to flaunt valour.

\section{Group of Monuments}

In all there are nine protected monuments at the site:

1. Saasu ni Vaav

2. Vahu ni Vaav

3. Temple with Shilalekh (popularly known as Kaleshwari Mata Mandir)

4. Ancient Temple (commonly known as Shiva Mandir)

5. Kund

6. Shikaar Madhi (popularly known as the Vakhatsinh Baavaji no Bungalow)

7. Bhima ni Chauri

8. Arjuna ni Chauri

9. Temple with three entrances (Hidamba Temple)

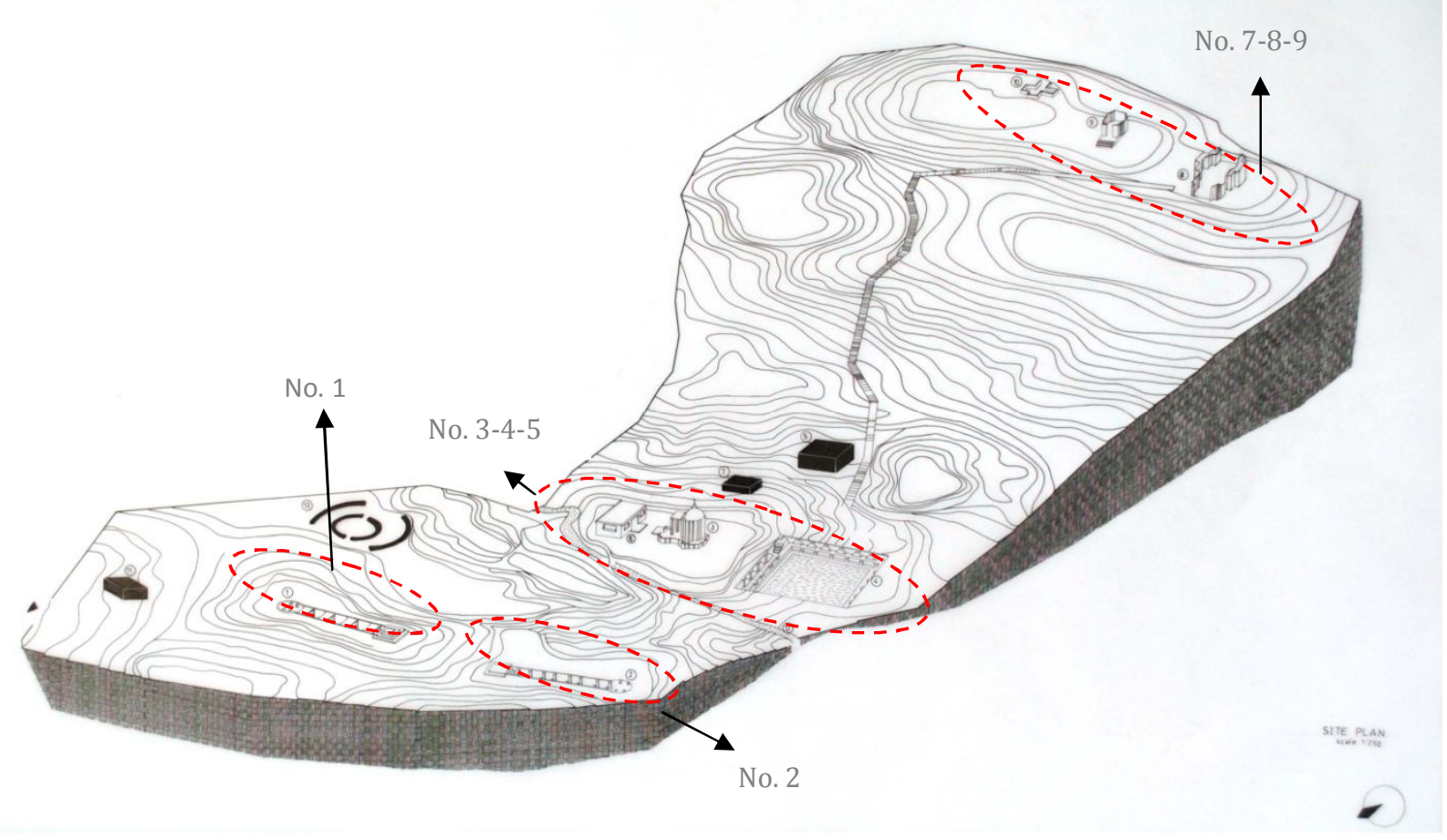

Fig. 6 Topography of Kaleshwari complex site showcasing location of all the listed monuments at the site 


\section{Saasu ni Vaav}
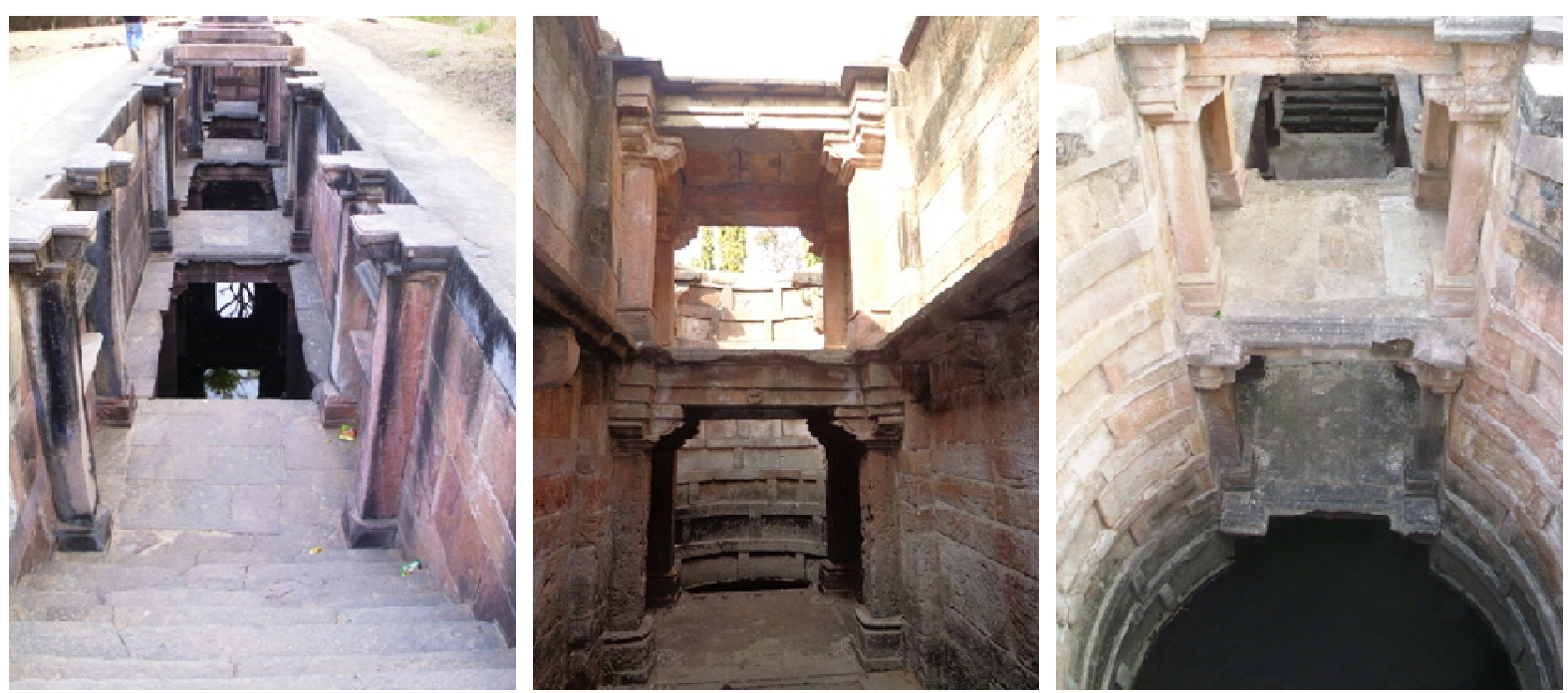

Fig. 7 Images of the Stepwell

Period: Stylistically the monument seems to be built in the $14^{\text {th }}$ or $15^{\text {th }}$ century A.D.

Type of monument: Vaav means a Stepwell. And a Stepwell is a water well with steps; it is a typology of building unique to western India. Essentially a device to contain water, it exalts to become a socio-religious institution - owing largely to its architectural manifestations. (Pandya, 2013)

Source of the Name: No evidence regarding the name of this Stepwell has been found. It is known by the popular name of Saasu ni Vaav - the name which is used by the local people.

Type of Stepwell: As per the $V^{1}$ stu texts, the Stepwell belongs to the Nanda type since it has only one entrance.

The monument seems to have been built by the community of Vaishnava people since the sculptures allied with it are all Vaishnava - The Dashaavtara panel, the Sheshashaayi Vishnu, etc.

Architectural Analysis: The detailed architectural analysis of the monument supplemented with measure - drawings of the same is depicted below:

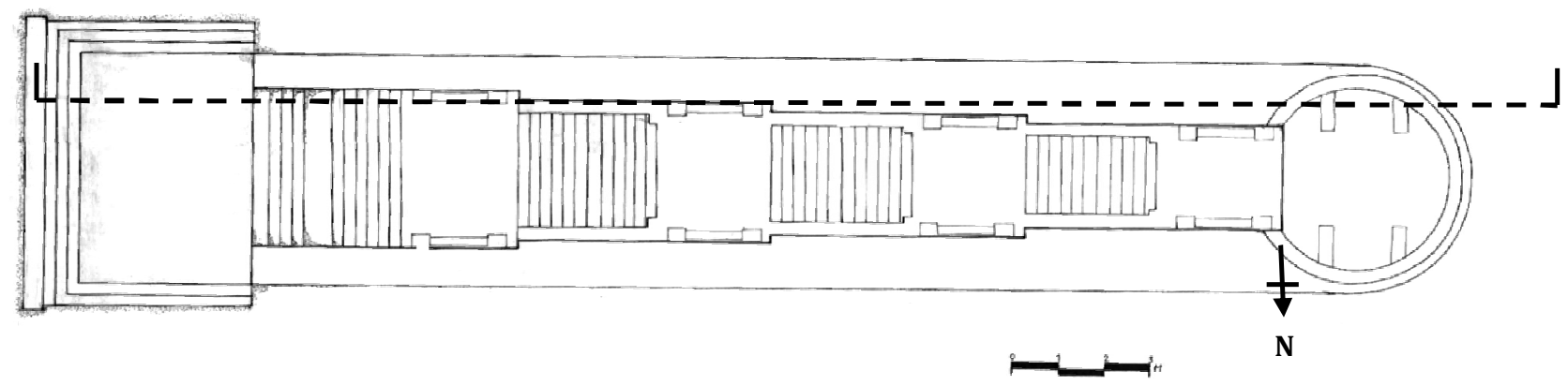

Fig. 8 Plan of Stepwell - Saasu ni Vaav 


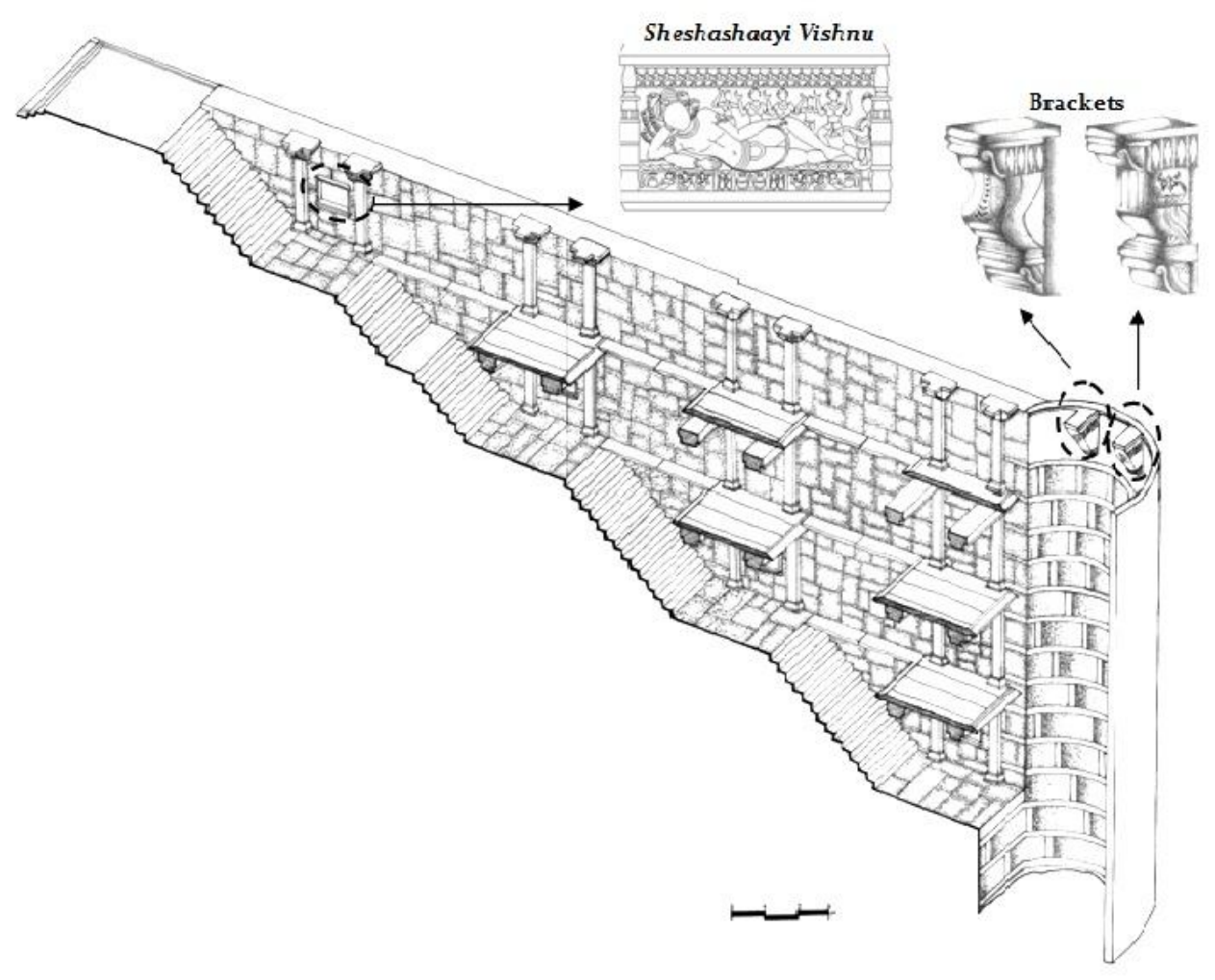

Fig. 9 Isometric Sectional view of Saasu ni Vaav

The monument is constructed based on design principles of symmetry, hierarchy, linearity, rhythm and order. The scale of the monument is smaller as compared to the famous Rani ki Vaav at Patan or Adaalaj ni Vaav at Ahmedabad. However, it is unique in its own respect and forms an integral part of a larger complex with several other monuments and a twin Stepwell - Vahu ni Vaav. This Vahu ni Vaav seems to have been built sometime later than the Saasu ni Vaav. This stepwell is also of the Nanda type and possesses sculptures of water gods on the structure.

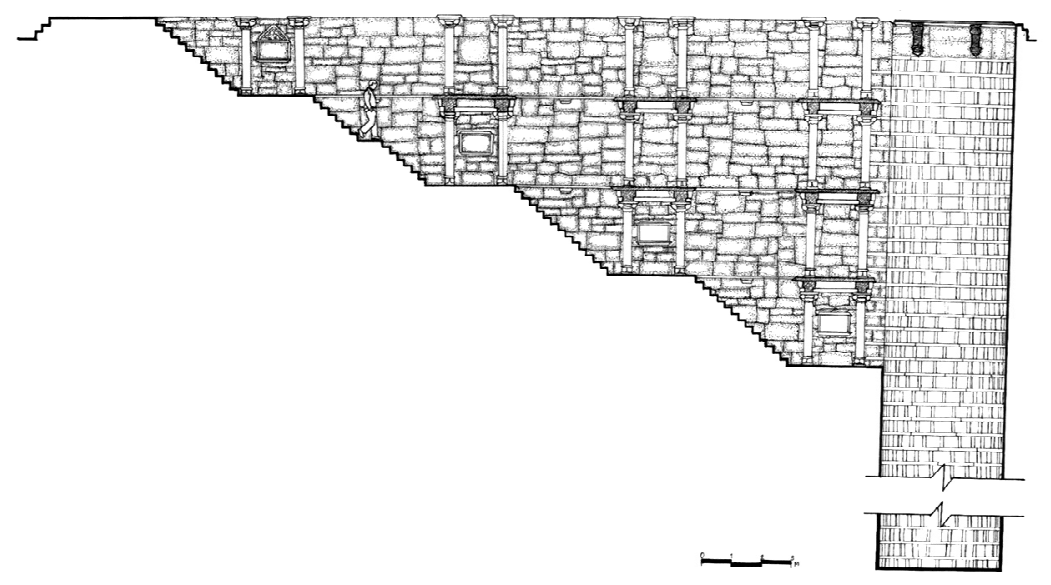

Fig. 1o Section of the Stepwell - Saasu ni Vaav 
As we go downwards through the progression of the steps every downward step changes the stationary point and the vanishing point of our view which gives a different perspective at each level. There are four main levels or landings after the main entrance in a sequential order. We can clearly observe the sculpted water gods in the monument as we go further in the hierarchy of spaces arranged in a linear progression.

The monument is planned on an East - West Axis such that the water well lies at the Western end of the Stepwell. The structure is constructed out of sandstone and is based on the structural system of post and beam construction. There are in all 40 columns along the sides of the Stepwell with 20 columns along each side. As evident from the above drawings, each column is studded with the stone walls. So, there are no free-standing columns. And each column has three brackets at the top in orthogonal axes. There are two brackets on the upper periphery of the circular hollow shaft of the well at the end of the trail. At each of the four main landings - the Mandapas there are niches (gavaaksha) on both side walls with sculptures of water gods and deities. The walls of along the downward staircase and landings upto the circular shaft showcase uncoursed stone masonry; while the inner wall of the hollow circular shaft displays coursed stone masonry. The walls on both sides along the downward progression were totally devoid of any ornamentation except for the sculptures in the niches flasking both side walls of all the four consecutive landings.

2. Vahu ni Vaav 3
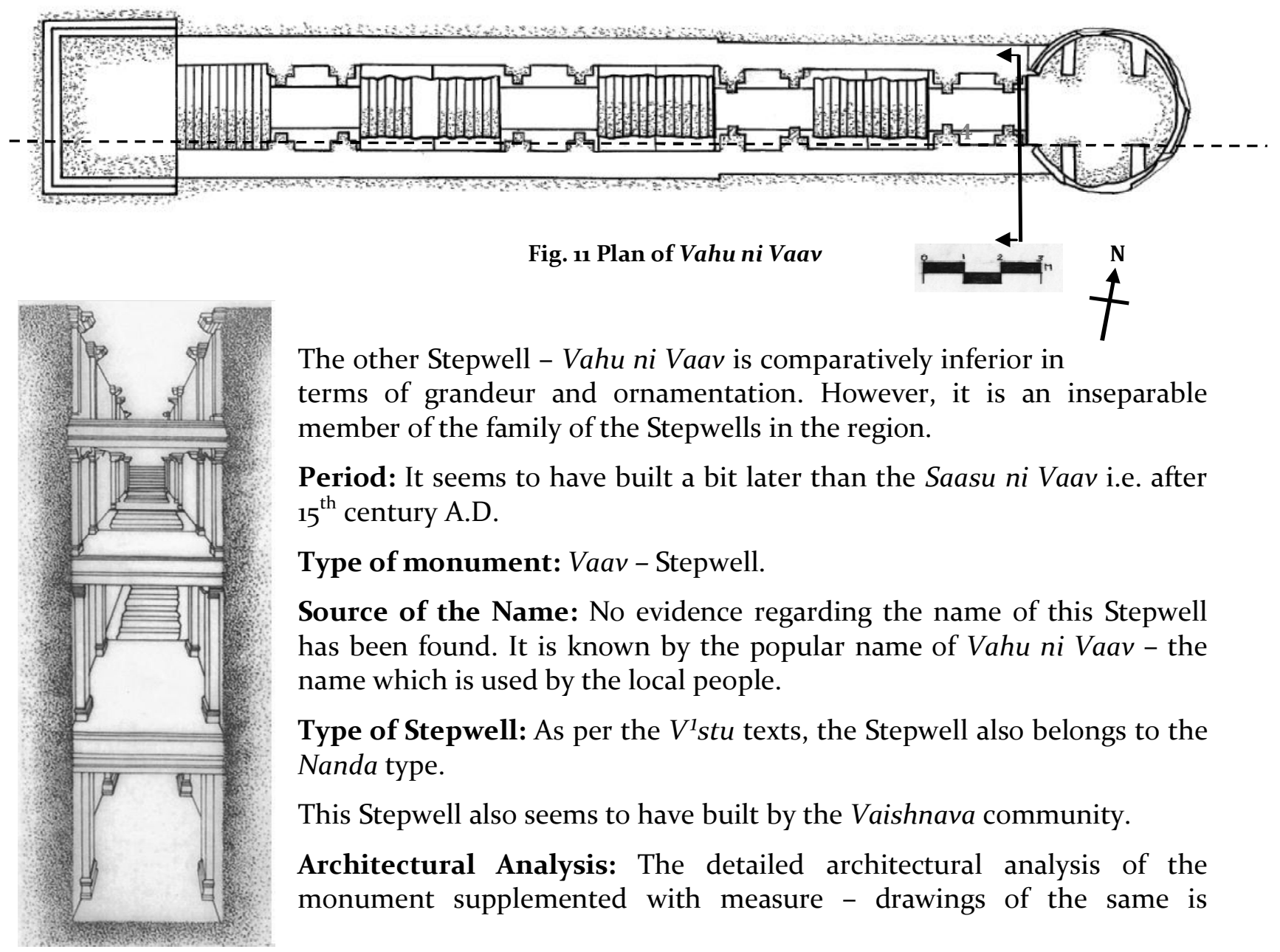

The other Stepwell - Vahu ni Vaav is comparatively inferior in terms of grandeur and ornamentation. However, it is an inseparable member of the family of the Stepwells in the region.

Period: It seems to have built a bit later than the Saasu ni Vaav i.e. after $15^{\text {th }}$ century A.D.

Type of monument: Vaav - Stepwell.

Source of the Name: No evidence regarding the name of this Stepwell has been found. It is known by the popular name of Vahu ni Vaav - the name which is used by the local people.

Type of Stepwell: As per the $V^{1} s t u$ texts, the Stepwell also belongs to the Nanda type.

This Stepwell also seems to have built by the Vaishnava community.

Architectural Analysis: The detailed architectural analysis of the monument supplemented with measure - drawings of the same is

Fig. 12 Section in Perspective along the width of the Stepwell 
depicted below:

This Stepwell is also constructed on an East-West axis with a slight tilt of 12 degrees in the layout. So, the layout of the monument is almost on the South-west to North-east axis but with a slight tilt only. And the downward progressions of the Stepwell are opposite or say, mirrored to the previous Stepwell in terms of layout.

Like the previous monument, this one is also constructed based on design principles of symmetry, hierarchy, linearity, rhythm and order. The scale of the monument is smaller than the previous Stepwell. This Stepwell also possesses four main levels or landings called Mandapa. At the end of the linear downward flight of steps and landings, is the circular shaft of the water well. The whole structure is load bearing and based on the system of posts and beams of stone. And the sides of the monument are made stone walls.

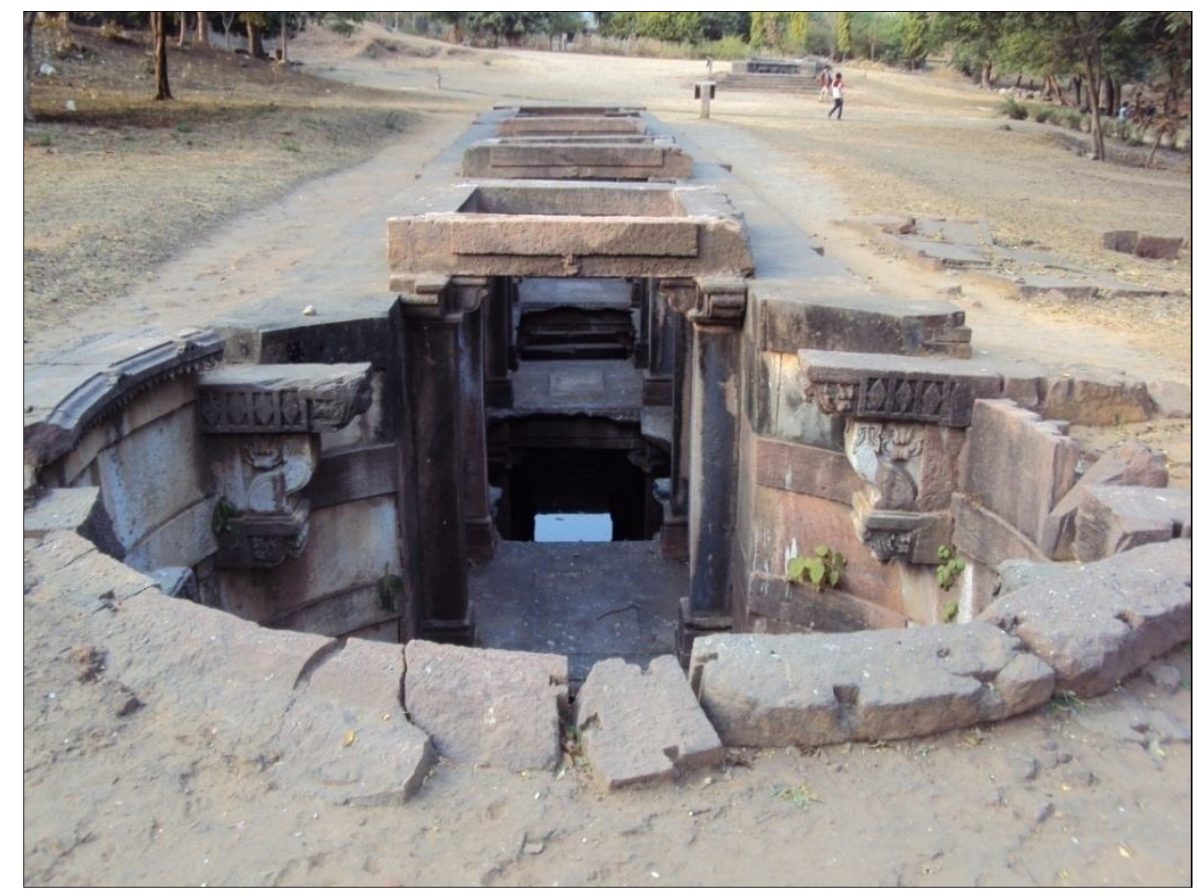

Fig. 13 View of the Stepwell from the Ground level

\section{Temple with Shilalekh (popularly known as Kaleshwari Mata Mandir)}

This structure seems to be the prayer hall of a temple which is now lost. The pillared hall itself is at present treated as the temple of the Kaleshwari Mata and the idol which is worshipped as Kaleshwari Mata is in fact the sculpture of Dancing Shiva - Nataraja and it is installed in the niche created as a later addition to the original structure. The original sculpture of Kaleshwari Mata is probably lost or not found. The hall has a short wall - Vedika besides the entry. Along the inner side of the short wall there is a seating of stone - Kakshasana. There are two openings in the centre of the two side-walls of the hall. There are 4 free standing composite style columns in the hall, supporting the roof slab as shown in the plan below: 

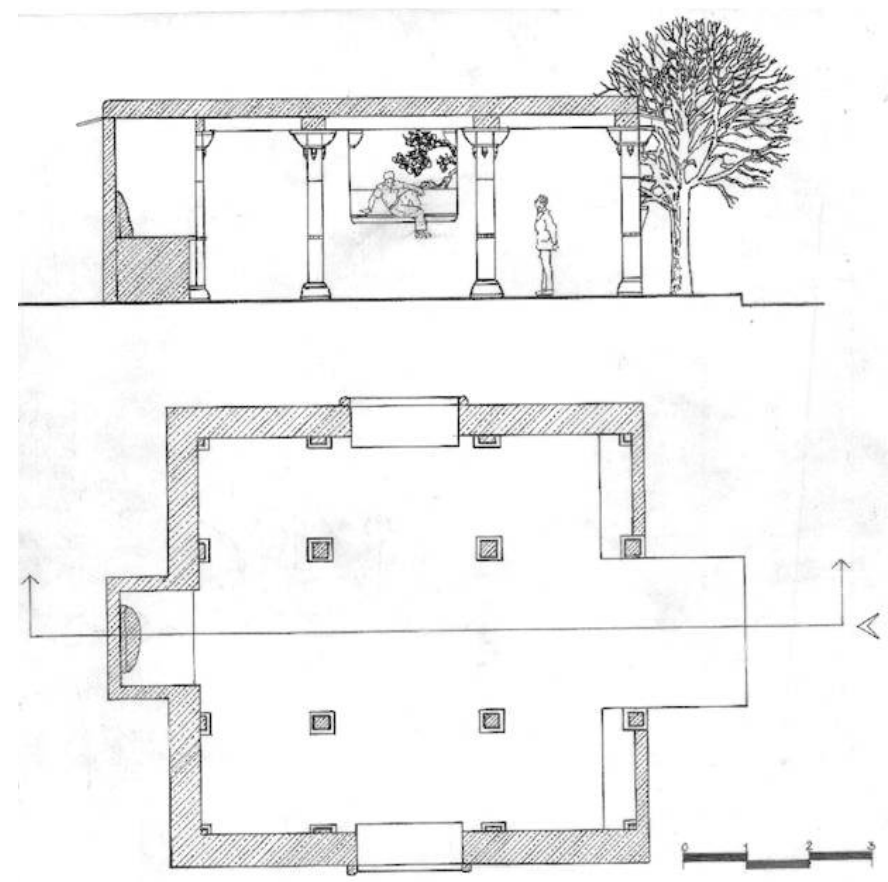

Fig. 14 Plan (above) and Section (below) of the structure

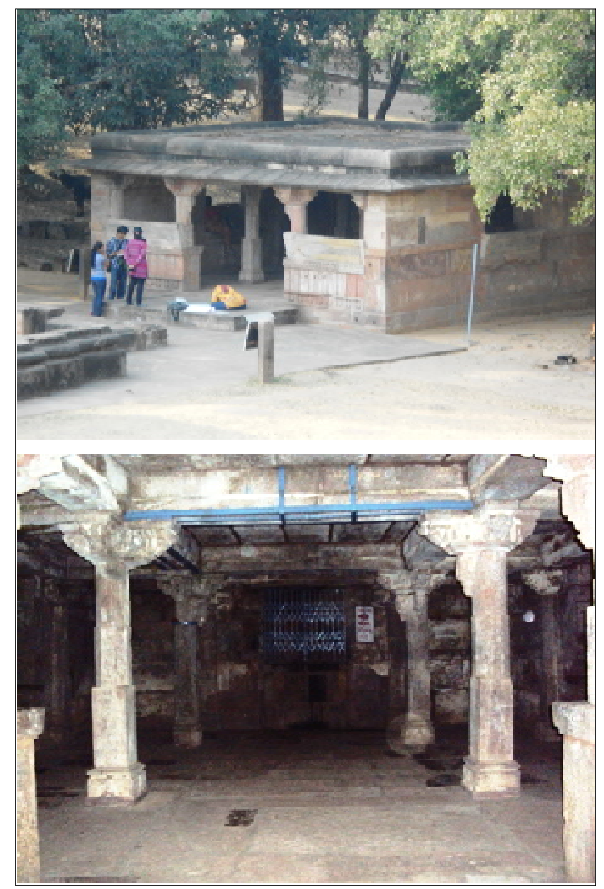

Fig. 15 Exterior (above) \& Interior (below) images of the structure

\section{Shiva Mandir}

According to Ravi Hajarnis, this monument was built in the $18^{\text {th }}$ century and locally popular as a Shiva Mandir as well as Ghummata valu mandir. It was a clumsy attempt to erect this temple with a reduced dimension lying inside the periphery of the Mulaprasada indicated by the surviving $10^{\text {th }}$ century plinth of the older structure whose lower courses are partially visible.

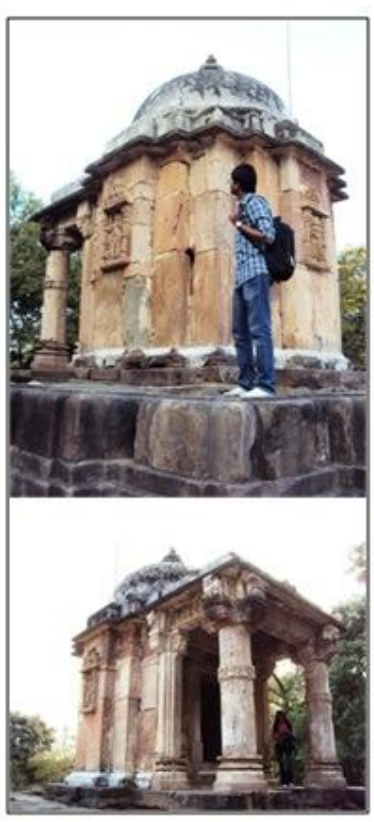

Fig. 16 Views of the temple
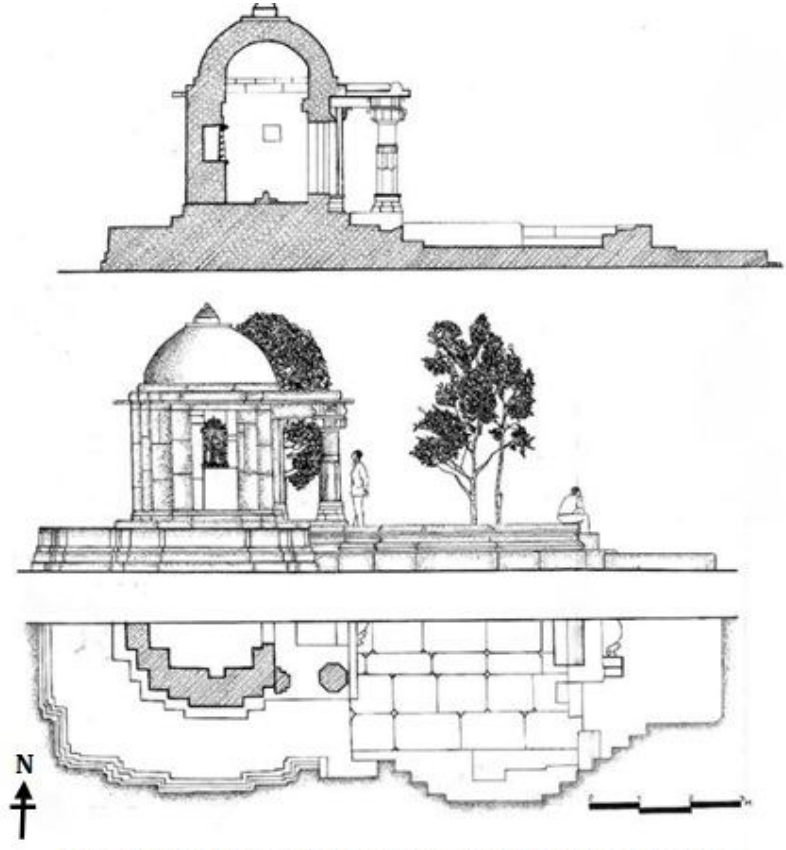

Fig. 17 Plan (below), Elevation (middle) and Section 
According to Dhaky the temple was, as evident from the plinth, falling in the tryanga (three buttressed) on plan and possessing thus a bhadra (central offset), karna (corner offset) and pratikarna (juxta-buttress). And since it possessed five buttresses from one corner to the other, it is a pañcaratha on plan. And as the name suggests it has a domical roof above its sanctum. As on plan the structure has only a sanctum and an entrance porch. In the exterior wall of the temple there are sculptures installed in the niches of three central offsets. The scale of the temple is smaller than any other structure in the complex.

\section{Kund}

A Kund is traditionally meant for bathing or washing, for ceremonial or ritual purpose. Its water is not meant for drinking. (Department of Archaeology, Govt. of Gujarat) This $11^{\text {th }}-12^{\text {th }}$ century squarish Kund or reservoir completes the set of earlier two monuments with all the three located on an East - West Axis with the Kund in the west and the temple in the east. The whole arrangement is comparable to that of the Modhera Sun temple complex. No other temple complex in Gujarat has a similar kind of an arrangement of a temple with a prayer hall, a separate hall and a water reservoir - all in a row. This is another instance of such kind after Modhera, yet inferior as far as ornamentation is concerned.

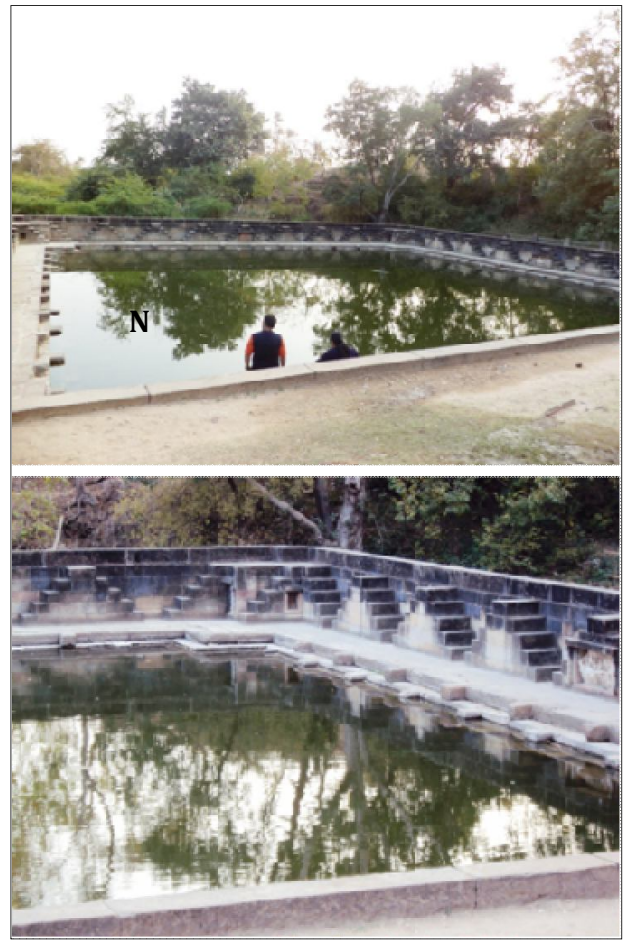

Fig. 18 Images of the Kund

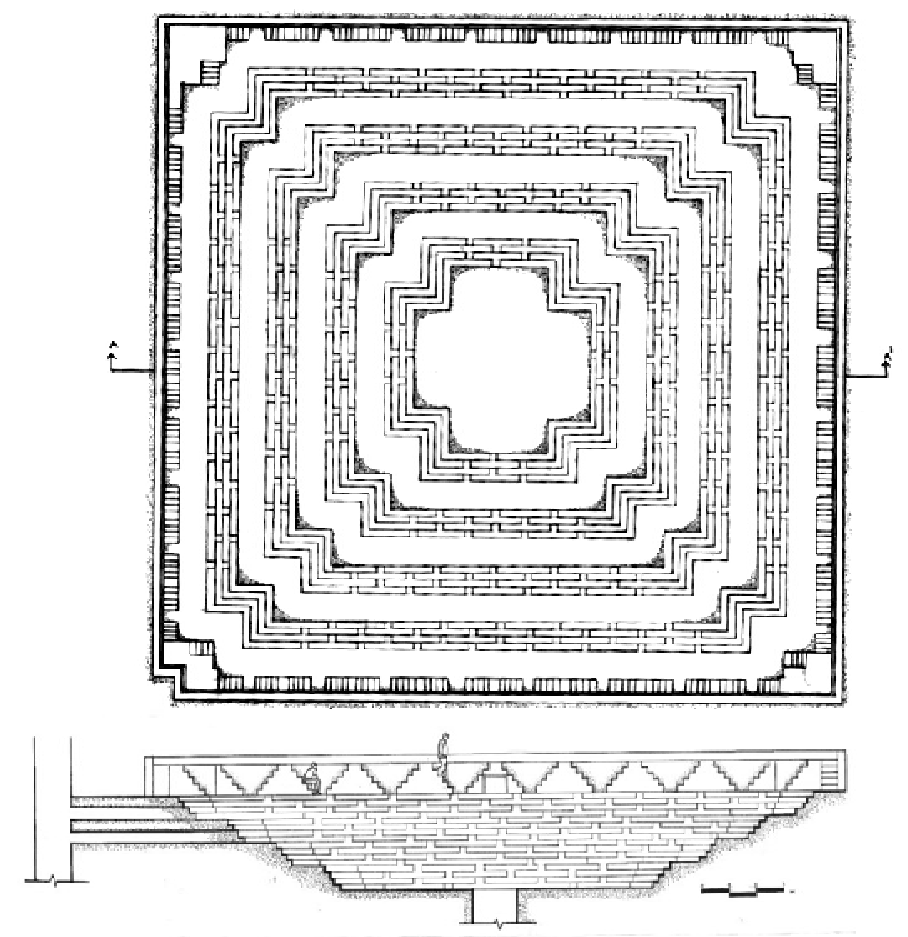

Fig. 19 Plan (above) and Section (below) of the Kund 
The composition of all the previous three monuments in a row as mentioned above is shown in the below drawing:

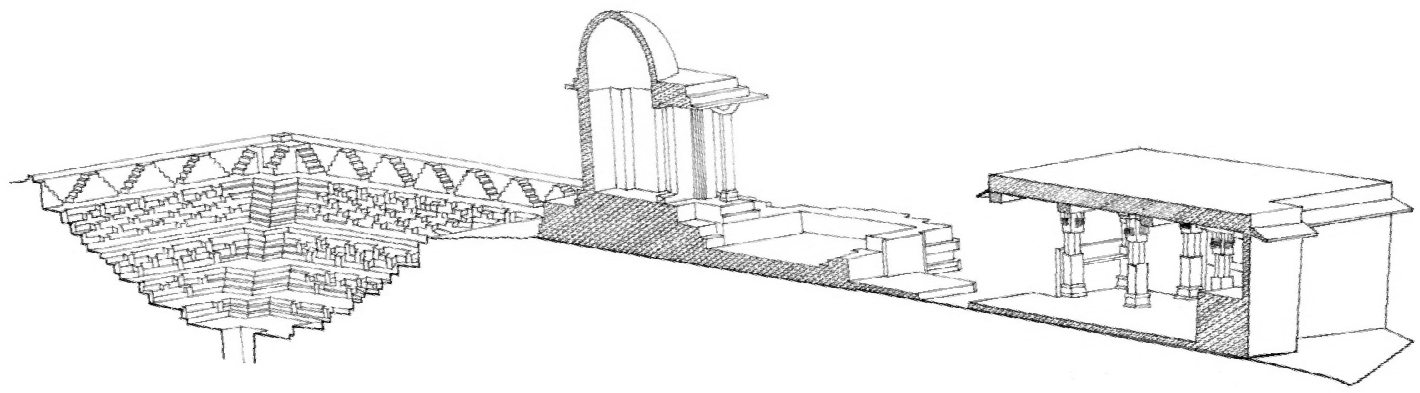

Fig. 20 Isometric View of the Section cut along the central axis of the temple, the pavilion and the reservoir

\section{Shikaar Madhi (Vakhatsinh Baavaji no Bungalow)}

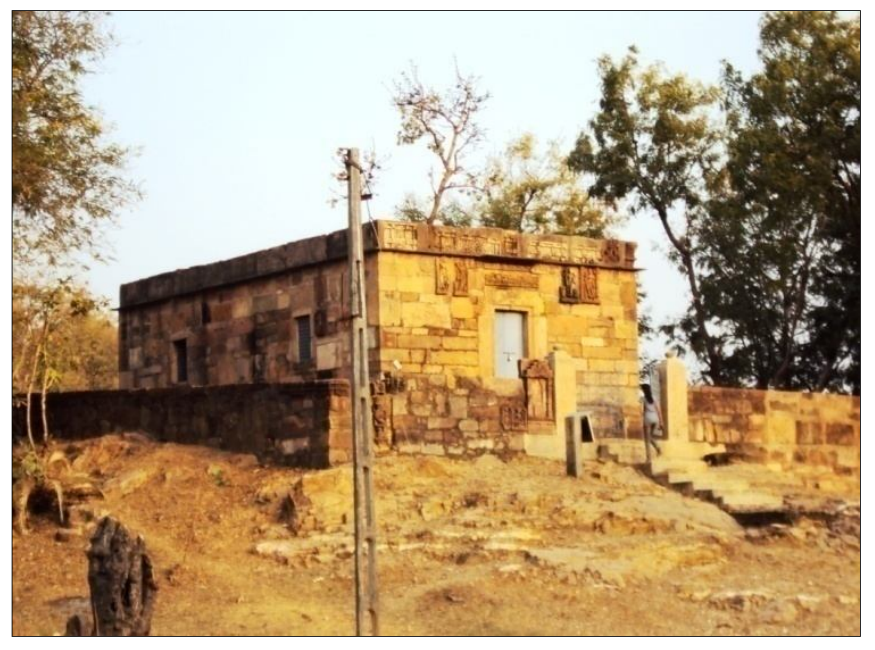

Fig. 21 View of the Bungalow

This structure is a later addition to the complex done by Vakhatsinh Baavaji wherein he has used the dilapidated and scattered parts of the other structures lying near the complex. The structure is popular as Shikaar Madhi or Vakhatsinh Baavaji no Bungalow. This name was coined because the royal family members of Lunawada used to come here for hunting.

This structure has no architectural significance except for the installed sculptures in the exterior walls which were originally a part of the other original monuments of the complex. These sculptures include Nrityaganesha, Mahishamardini, Vishnu, Chamunda, Varahi and Darpan kanya.

\section{Bhima ni Chauri}

This monument is also a Shaivite temple locally popular as the Bhima ni chauri. At present the temple is in a ruined condition. But still most parts of the temple can be assumed based on the existing portion of the structure. Built in the architectural style suggestive of the $14^{\text {th }}-15^{\text {th }}$ century, this Shiva temple falls into the 'tryanga' type of temples. Except the 4-pillared entrance porch and the lower part of the Mandapa and sanctum, it is recently restored having noticeable carvings at the sanctum threshold and lintels of the Mandapa. The orthogonal plan of the sanctum is pañcaratha. The horizontal areas of the temple consist of a praggriva (entrance porch), a Mandapa (prayer hall), an antarala (vestibule) and a garbhagriha (sanctum). The elevation of the exterior face of the sanctum consists of a plinth, an exterior wall and the super structure which is now lost. The prayer hall has Vedika (short wall) along its sides with short columns in a grid on top. All the short columns are of composite type. The super structure of the prayer hall and the entrance porch is now lost. 
81 | The Chitrolekha Journal on Art and Design, Vol. 1, No. 1, 2017
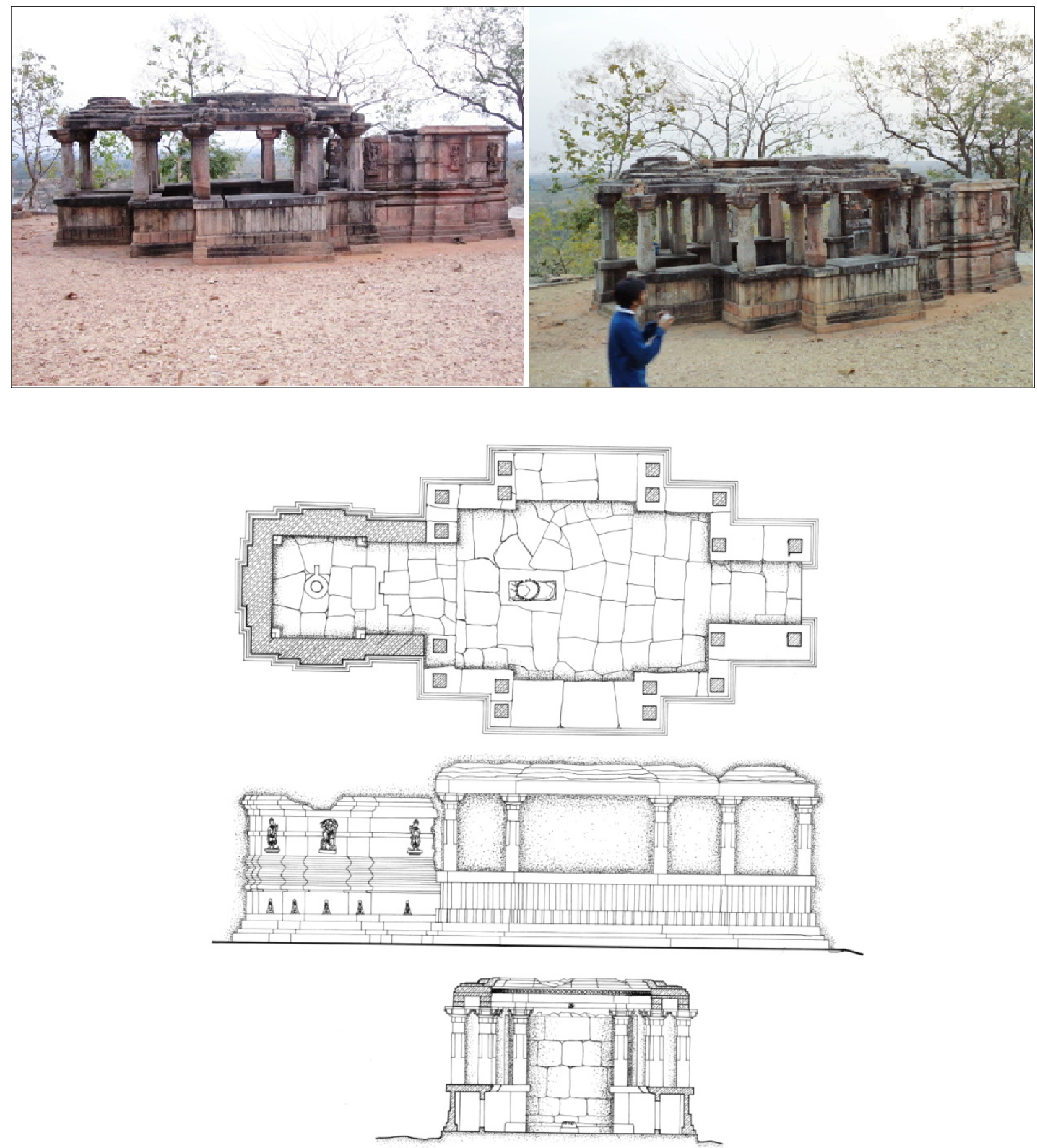

Fig. 23 Section (below), Side elevation (centre) \& Plan (above) of Bhim ni Chauri

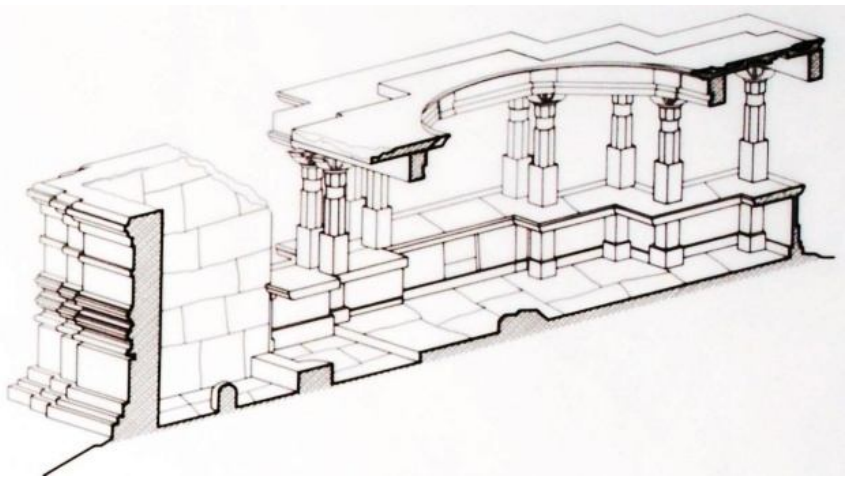

Fig. 24 Isometric view of Bhima ni Chauri 


\section{Arjuna ni Chauri}

This monument is at the topmost elevation of the site at Kaleshwari. The name mentioned above is the popular name of the monument used by the localites. There is no literary or authentic evidence of the same found yet. It is much superior in terms of ornamentation and carving as compared to the previously described temple. This fact is clear from the remains of the door - frame of the monument. The temple is however of a smaller scale as compared to the Bhima ni Chauri.

As evident from the adjacent image, the temple consisted of a sanctum and an entrance porch only. The plan of the sanctum

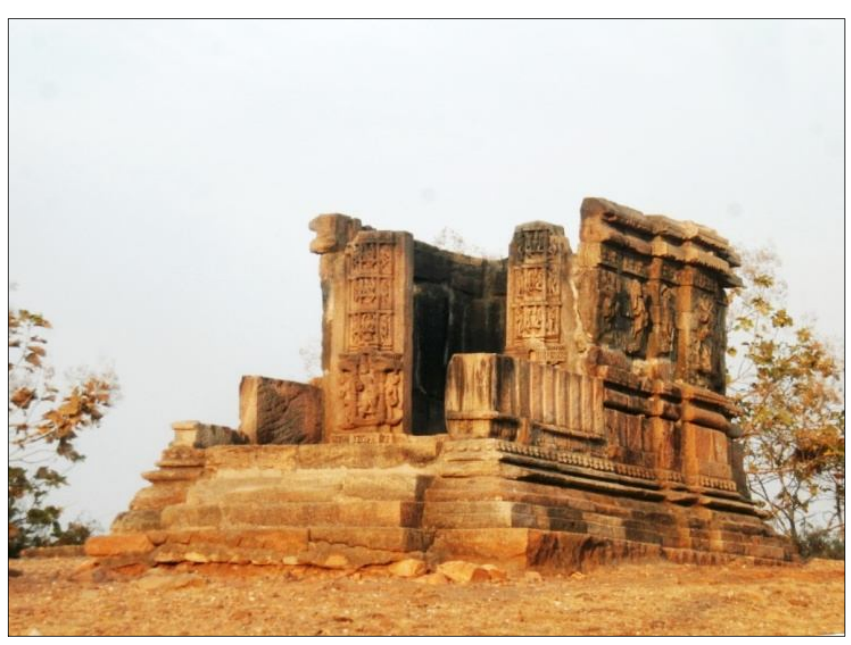

Fig. 25 Arjuna ni Cauri is orthogonal and pañcaratha. Today the super structure of the temple is completely lost. What remain are the exterior wall of the sanctum and the plinth of the temple. The exterior wall of the sanctum has sculptures on each of the buttresses.

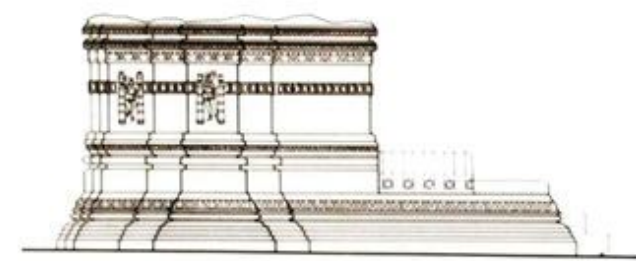

Side Elevation

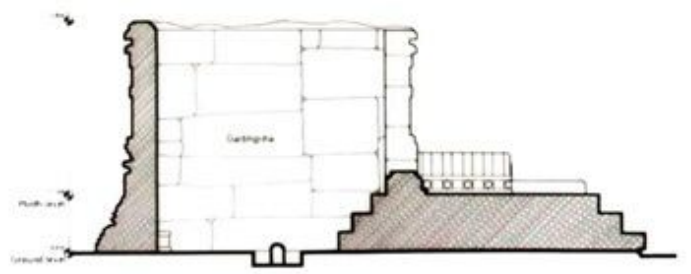

Section

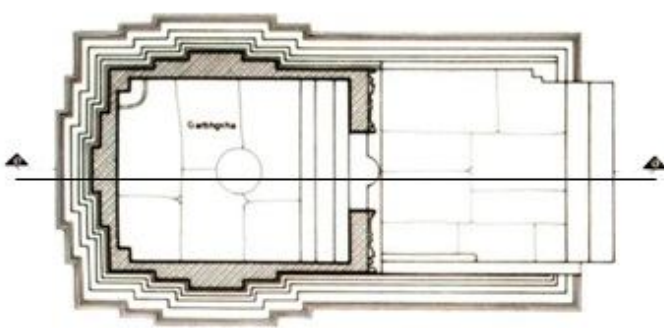

Plan

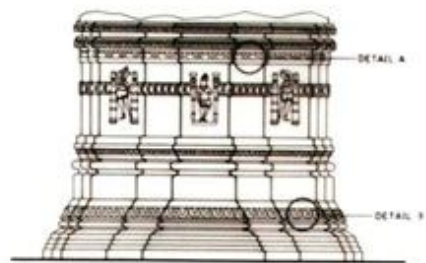

Rear Elevation

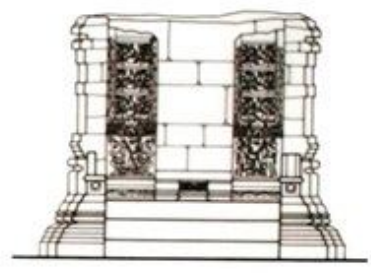

Front Elevation

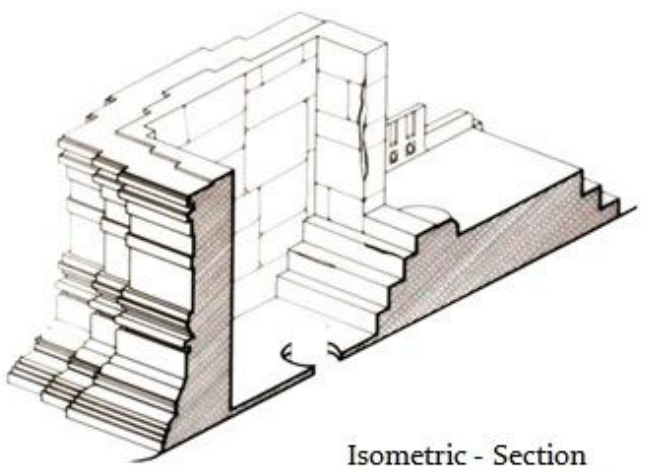

Isometric - Section

Figure 26 Drawings of Arjuna Chauri 
8. Temple with three entrances (Hidamba temple)

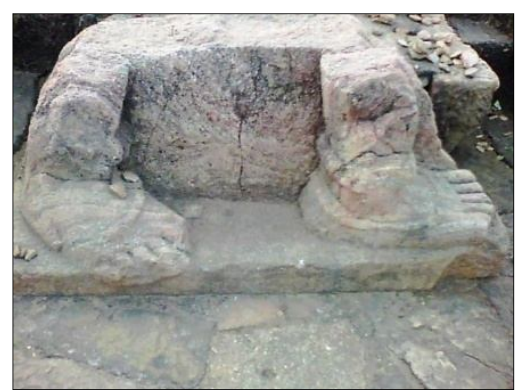

Fig. 27 Remains of the idol in Hidamba temple

This temple is popularly known as the Hidamba temple. The temple has three entrances which is why it is called the temple with three entrances. The remaining portion of the idol installed in the temple is popularly known as Bhima ane Hidamba na pagla. The whole structure of the temple is lost completely except for the lower wall portions and some portions of the plinth. Apart from these there are no details of the ornamentation or sculptures which must have been a part of the monument.

\section{Way forward}

There is a further scope of research for carrying out restoration at the site. This is essential to re - assemble the numerous parts of the lost structures lying scattered at the site.

\section{Acknowledgements:}

1. All drawings produced here are prepared by the First-year students of Parul Institute of Architecture and Research (PIAR), Batch 2012 as a part of their RSP - Study Tour conducted in 2013.

2. All photographs produced in the article are taken during the site visits and are published with the courtesy of the Department of Archaeology, Gujarat State.

3. The Authors are indebted to Late Shri Ravi Hajarnis for his in-depth discussions on the subject and constant guidance.

\section{References}

Department of Signage at Kund at Kaleshwari complex, Dept. of Archaeology, Govt. of Gujarat, Archaeology Lavana, Panchmahal, Gujarat, India.

Gandhi, R. Kaleshari. "Kumar" (Gujarati), October 1953, p. 371.

Hajarnis, R. Kaleshvari Smarak Samuha, "Gujarat” - weekly journal of the Government of Gujarat, 1990, p. 33.

Majumdar, M. R. “Kaleshari”, State Transport Department, 1958.

Pandya, Y. Spatial Narratives in Traditional Indian Architecture: An Interpretation for Contemporary Relevance, "AURA”,Vol.- I, (Ed.) Maulik Hajarnis and Bhagyajit Raval, 2013.

\section{Glossary}

Antarala - vestibule

Darpanakanya - Female with a mirror

Dashaavtara - Ten incarnations

Dungar - Mountain

Garbhagriha - sanctum

Gavaaksha - niche

Kund - Water Reservoir

Mata-Mother
Mandapa (in case of a temple) - prayer hall

Mulaprasada - Main shrine

Naal - Valley

Nrityaganesha - Dancing Ganesha

Pagla - Footprints

Pañcaratha - with Five projections (from one

corner offset to the other)

Praggriva - entrance porch 
71 | The Chitrolekha Journal on Art and Design, Vol. 1, No. 1, 2017

Rani ni Vaav - Queen's Step-well

Saasu ni Vaav-Mother-in-law's Step-well

Sheshashaayi Vishnu - Lord Vishnu sleeping on

the Shesha Naga

Shikaar Madhi - Platform for Hunting
Shilalekh - inscription

Tryanga - with three main parts

Vaav-Step-well

Vahu ni Vaav - Daughter-in-law's Step-well

Vaishnava - Cult following Lord Vishnu 